\title{
Syrphid aphidophagous predators in a food-web context
}

\author{
FRANCIS GILBERT
}

School of Biology, Nottingham University, Nottingham NG7 2RD, UK; e-mail: francis.gilbert@nottingham.ac.uk

Key words. Syrphidae, hoverfly, predator, community, emergent properties, specialisation, holism

\begin{abstract}
The main influences on the specificity of hoverfly larvae (Diptera: Syrphidae) to particular aphids are outlined. There are four main ones: aphid species, host plant, parasitoid impact and the presence of ants. Studies in the literature are used to illustrate the effect of these factors on larval performance. The use of single components of fitness as measures of performance can be misleading: only "individual fitness" includes all the appropriate components of survival, development time and reproduction. Even generalists appear to choose among aphids on the basis of expected fitness. A new level of complexity is therefore required in studies of food specificity in predatory syrphids.
\end{abstract}

\section{INTRODUCTION}

In an essay of dazzling scope, Simberloff (1980) pinpointed the major problem of ecology as one of levels of organisation, of hierarchy in the natural world. Above the level of the individual, there are at least four more layers in a hierarchically ordered Nature, namely the population, the species, the community, and the ecosystem. Pace ecosystem ecologists, Simberloff argued that there are no properties of communities or ecosystems that cannot be understood by a study of individual component species. His opinion was that adherence to non-Darwinian holistic concepts such as the "community" or "ecosystems" stems from Platonic Idealism, and that studies at this level are quite simply a waste of time unless demonstrated to require it.

How do we demonstrate the necessity of holism? Applying Darwinian thinking to the hierarchy of Nature is clearly a more difficult thing to do than to apply it to a field such as animal behaviour. Whilst the true impact of Darwinian thinking was felt by ethologists in the late 1960 s, it took at least another 10 years for theoreticallyminded ecologists to appreciate it. Furthermore, plant ecology as a field worked through the paradigms of the Clementsian superorganism to Gleasonian individualism in the 1930s, but animal ecology only learned the same lesson in the 1980s (Jackson, 1994). Thus in a very real sense, theoretical ecology went back to basics in the 1980 s and really started again from the null hypothesis that animal communities were basically non-interactive, Gleasonian entities. Now once again, with increasing evidence for the importance to terrestrial ecology of tritrophic interactions (e.g., Ode et al., 2004), trophic cascades (Matsumoto et al., 2003) and metacommunity effects (e.g., Leibold et al., 2004), we have returned to the paradigm of interactive communities, but grounded very much more in truly Darwinian basics.

I am interested in understanding the feeding specializations of the aphidophagous Syrphidae (Diptera), and in this paper I review whether we need to consider solely the trophic relationship between these insect predators and their prey, or whether we require a larger scale, food-web approach.

Most insects are rather specific when choosing their food (Schoonhoven et al., 1998), including predators (Hodek, 1993), and even generalist predators display a hierarchy of preferences for different hosts (Sadeghi \& Gilbert, 1999, 2000a). What determines whether any particular insect will feed on any particular food? The idea of an interactive community suggests that the answer to this question lies not merely in the availability and suitability of the food itself, but also in the embedded network of the food web within which the particular feeding relationship occurs.

Until relatively recently, the main two aspects emphasized as important in understanding specialization were specific just to the trophic relationship itself, namely the foraging behaviour of ovipositing females among available hosts (especially in species with relatively immobile larvae), and the subsequent performance of the developing larvae (e.g. Tauber \& Tauber, 1987). Both of these involve food availability and suitability. Among herbivores, the balance of nutrients that the hostplant provides is normally rather different from what they require (the recent and burgeoning field of ecological stoichiometry), and hence the biochemical and physiological ability of the larva to cope with the food is important. In the case of predators, there are fewer differences between nutritional requirements and what prey provide: as a result the costs of capture, the toxin content of prey, and the mortality risks of foraging are probably relatively more important (e.g. Malcolm, 1992).

In searching among food types, gravid females appear to have a hierarchy of preference (e.g. Courtney et al., 1989; Sadeghi \& Gilbert, 2000a,b) with a variable outcome because, for example, they become less selective with increasing age. Jaenike (1990) concluded that a female should oviposit in response to a particular food item early in her search if (1) this item is very suitable for her larvae, (2) the probability of finding an alternative is low, (3) the egg load is high or (4) alternative food items 


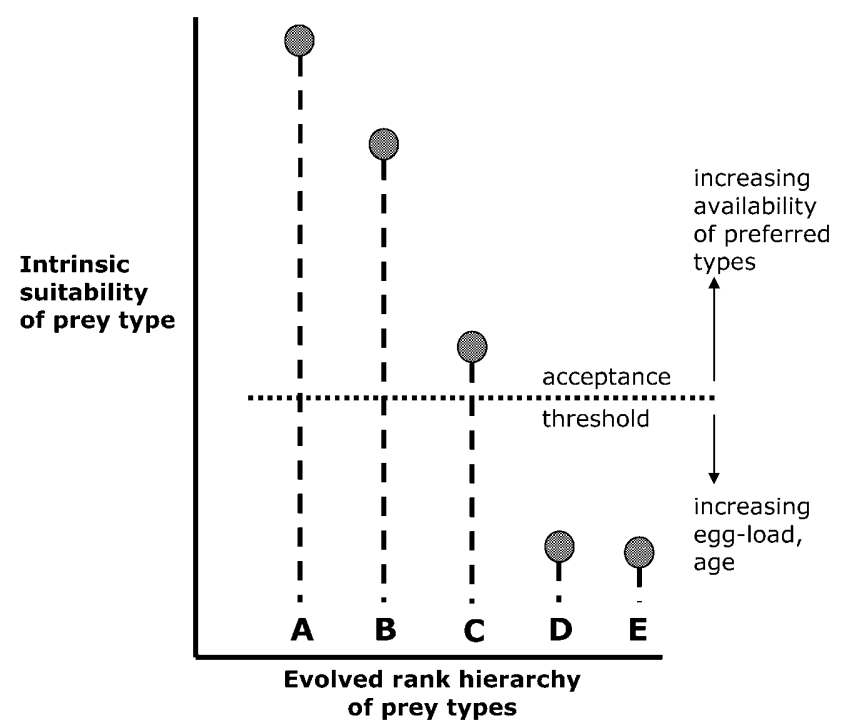

Fig. 1. The hierarchy-threshold model of host choice (Courtney et al., 1989) applied to a gravid female syrphid searching among a set of possible prey (A to E). The assumptions of this model include that: slow (co-)evolutionary processes have moulded population genetics such that each individual female has an intrinsic preference for each prey type, resulting in a rank order of preference among prey types that does not change throughout the female' lifetime; females that accept a low-ranking prey type will also accept all higherranking types; actual acceptance of an encountered prey type depends on whether the stimulus of that prey exceeds the current acceptance threshold (which varies with factors such as current availability of prey types, age or eggload).

are unpredictable in space or time. In their hierarchy threshold model (Fig. 1), Courtney et al. (1989) formalized these ideas about food choice by individual insects. In this model, females possess an intrinsic evolved degree of preference for each food type, producing a rank order of preference among prey that does not change throughout an individual's lifetime; individuals accepting a low-ranking food type will also accept all higherranking types; and actual acceptance of an encountered type depends on whether the stimulus of that food type exceeds the current motivational threshold (which can vary with factors such as age or egg-load). The model is particularly useful because it synthesizes two disparate strands of adaptive explanations of specialization (Berenbaum, 1990), one involving slow processes of evolutionary change based usually on various sorts of tradeoff and coevolution, and the other invoking optimal foraging and concentrating on the behavioural flexibility of the individual in response to variation in ecological conditions, acting via "rules of thumb".

A positive relationship between oviposition preference and larval performance is thought to be crucial (Janz et al., 1994). However, in empirical tests of this prediction, observed relationships range from good to poor. Reasons put forward for the variation in outcome of these experiments include the measures of performance used (McGraw \& Caswell, 1996), or differences in the ability of larvae to move to alternative food sources (Price, 1997, p. 384-390). Evolutionary biologists insist on measuring performance as overall fitness, and hence including survival, growth and subsequent adult reproductive output (Nylin \& Janz, 1993). In practice, larval performance has usually been estimated from only one or two components: more than $50 \%$ of preference-performance studies have taken only one or two parts of the insect' life-cycle into account. This leads to difficulties in interpreting the results precisely because components of fitness are used as surrogates for fitness itself: as McGraw \& Caswell (1996) point out, responses of different components of fitness to variation in the environment can be different in both sign and magnitude. There are additional difficulties. For example, relating laboratory data to the field situation is problematic: survival in the field is the key parameter for natural selection rather than the laboratory measure of survival solely due to food quantity and quality.

Many discussions in the literature have a rather typological concept of specialization in insects. In fact, variation in degree of specialization occurs at all levels. The most obvious is among species, but important variation occurs among populations within species (Fox \& Morrow, 1981), and among individuals within populations (Ng, 1988; Schoonhoven et al., 1998; Sadeghi \& Gilbert, 1999). The consequences of this variation are profound. To take a single example, consider the textbook cases of Müllerian and Batesian mimetic butterflies (Ritland, 1991; Moranz \& Brower, 1998). In the standard story, Monarch (Danaus plexippus) and Queen (Danaus gilippus) butterflies sequester cardiac glycosides from their milkweed (Asclepiadaceae) hostplants, making them toxic; there exists a harmless Batesian mimic, the Viceroy (Limenitis archippus). However, some Danaine caterpillars feed on milkweeds with low toxin levels, or do not sequester toxins at all even if present, and populations differ in this propensity. Thus individuals and populations of Danaine "models" vary greatly in toxicity. Futhermore, at least some Viceroys are toxic, based on completely different chemical components.

Thus characterizing a species as a "generalist" or a "specialist" can be misleading, even though most entomologists think about their study species in this way. Species can indeed consist of individuals all of whom are specialized to the same particular food type. However, a generalist species may be made up of specialized populations, each specializing on different food types; or it may consist of generalized populations made up of individuals each specializing on a different food; or it may be made up of truly generalized individuals. Real populations probably consist of mixtures of generalized and specialized individuals.

Increasingly the importance of the food-web context to our understanding of feeding specialization is being documented and explored (Price et al., 1980; Müller \& Godfray, 1999; Ode et al., 2004). Often these are called "tritrophic" relationships, but they are much more extensive and sophisticated than merely including an extra trophic level: plants recruit natural enemies to fight herbivores (de Moraes et al., 1998; Kessler \& Baldwin, 


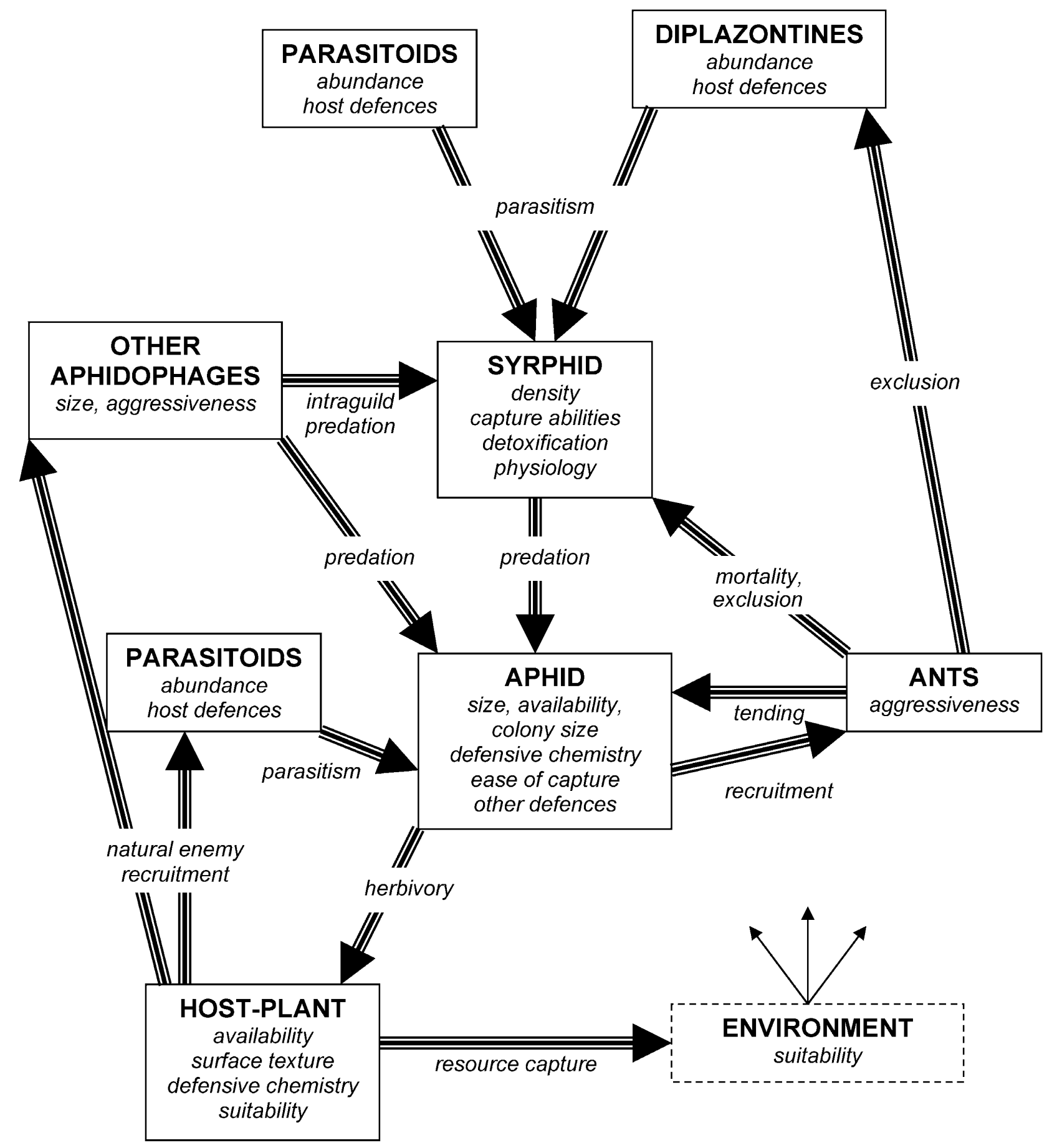

Fig. 2. Influences on the degree of specialization of aphidophagous syrphids.

2001); herbivore defences vary on different plants (de Moraes \& Mescher, 2004); intraguild predation modifies natural enemy impact (Borer et al., 2003); trophic cascades occur in aphidophage communities (Matsumoto et al., 2003); effects occur over more than three trophic levels (Harvey et al., 2003); and community level effects are assuming greater and greater importance as our knowledge of them expands (e.g. Rutledge et al., 2003).

I shall outline selected aspects of the literature about aphidophagous syrphids to place their biology in this rela- tively new context. In this I consider the following elements to be important:

- prey availability in the habitat, and prey suitability: it needs to be borne in mind that within a particular predator species there can be substantial individual and/or population variation in the suitability of particular prey items.

- mortality from natural enemies: intraguild predators, predators, parasitoids

- mortality of natural enemies caused by their natural enemies (i.e. the 4 th trophic level)

- the impact of third parties such as ants 


\section{PREY AVAILABILITY AND SUITABILITY}

Aphids are classic examples of prey that are ephemeral in space and time, requiring special adaptations to be able to take advantage of them. Sometimes they are hugely abundant, but even abundant colonies can disappear over very short time scales. Aphids have also evolved a variety of behavioural, morphological and chemical defences against their predators and parasitoids. This range of defences can be categorized under the headings of: wax or "wool" production, galling, toxic chemicals, soldier instars, escape behaviour and the recruitment of attendant ants (Shibao, 1998; Branquart, 1999). There are specialist syrphid predators adapted to overcoming every one of these defensive strategies.

The evidence that is used to demonstrate differences in the degree of specialization of syrphid predators fall into a number of categories: catalogue data, field distribution from single studies of multiple aphid and syrphid species, and studies of oviposition preference and larval performance. Notice that all of these elements consider the predator-prey relationship alone, independent of its food-web context.

\section{Catalogues}

The non-taxonomic literature on the Syrphidae consists of at least 5500 papers published in more than 1400 journals (Gilbert, unpubl.). The subset that mentions the feeding ecology of aphidophagous syrphid larvae consists of more than 1000 papers scattered among a large number of journals (Rojo et al., 2003). The information of these papers is dominated by records of the larvae of single species feeding on single aphid species on a single plant, usually a crop. Our main, typological ideas about the specificity of each species in feeding on different aphids overwhelmingly derive from the aggregate impressions of this body of literature. Collations of such records are well known to be potentially very misleading (e.g., Askew \& Shaw, 1986).

Collecting together the information from these papers, there are 7000 records of 333 hoverfly species from 41 genera mentioned feeding on a total of almost 850 prey taxa. The species with the most records is the Old World Episyrphus balteatus (Table 1) with almost 900 records

TABLE 1. The number of prey taxa and the number of records in the literature for a selected number of common and rare species of aphidophagous Syrphidae (data mostly from Rojo et al., 2003).

\begin{tabular}{lrc}
\hline Species & Prey taxa & $\begin{array}{c}\text { No. of } \\
\text { records }\end{array}$ \\
\hline Episyrphus balteatus (De Geer) & 234 & 890 \\
Eupeodes (Metasyrphus) corollae (Fabr.) & 124 & 421 \\
Scaeva pyrastri (L.) & 116 & 376 \\
Syrphus ribesii (L.) & 128 & 374 \\
Sphaerophoria scripta (L.) & 87 & 265 \\
Ischiodon scutellaris (Fabr.) & 49 & 187 \\
Eupeodes (Metasyrphus) luniger (Meigen) & 64 & 146 \\
Sphaerophoria contigua (Macq.) & 54 & 125 \\
Melangyna (Meligramma) cincta (Fallen) & 5 & 11 \\
Toxomerus corbis (Walker) & 1 & 1 \\
\hline
\end{tabular}

on some 250 taxa, and there are other species with similarly high numbers of recorded prey taxa: Eupeodes corollae, Scaeva pyrastri and Syrphus ribesii, amongst others. One might be forgiven for concluding that these were super-generalists that will feed on almost any kind of prey. At the other end of the spectrum are species such as Melangyna (Meligramma) cincta with only five prey types ever recorded - it is usually thought of as a specialist on beech aphids (Phyllaphis fagi). Many species have only ever been recorded once as larvae: the North American species Toxomerus corbis, for example, has only been recorded once, feeding on the Red Spider Mite (Tetranychus sp). Clearly the assessment of degree of specialization is confounded by relative abundance: common species are recorded much more frequently as larvae, and hence tend to be found feeding on more prey types as a consequence, even if there were no differences in specialization.

The literature is naturally very biased towards studies of crop pests, and hence it is not surprising that the major pest aphids are the most frequently recorded prey of aphidophagous syrphids (Table 2): Brevicoryne brassicae and Aphis fabae dominate, the former reflecting the enormous number of studies of cabbage and its pests.

TABLE 2. The number of times particular taxa have been recorded as prey of aphidophagous Syrphidae (data mostly from Rojo et al., 2003).

\begin{tabular}{lc}
\hline Prey species & Number of records \\
\hline Brevicoryne brassicae & 461 \\
Aphis fabae & 426 \\
Myzus persicae & 275 \\
Aphis gossypii & 249 \\
Aphis craccivora & 160 \\
Hyalopterus pruni & 134 \\
Lipaphis erysimi & 126 \\
Acyrthosiphon pisum & 109 \\
Rhopalosiphum maidis & 107 \\
Myzus cerasi & 105 \\
Sitobion avenae & 101 \\
Hyperomyzus lactucae & 100 \\
\hline
\end{tabular}

It is very difficult to tell much from such lists of prey. Each record has to be treated as equivalent in value, and there is no information about the relative frequency by which prey are used as food. The basic information required is the same as for any study of niche relationships, namely the abundances of the available prey types in the habitat, and their usage by different predator species: unfortunately there are hardly any such studies in the literature. There are a small subset of studies (Table 3) that have recorded several species of prey and/or several species of hoverfly at the same time. These form only $8.3 \%$ of the literature on aphidophagous syrphids. I have separated them into four categories according to the type of evidence they provide: field distribution, larval performance, oviposition preference and intraguild predation (Table 3). 
TABLE 3. The number of studies on aphidophagous Syrphidae in the literature, sorted into categories relevant to the understanding of prey specialization.

\begin{tabular}{lrl}
\hline Number of papers on & N & Examples \\
\hline field distribution of larvae on multiple hosts & 20 & Rotheray, 1980; Mizuno et al., 1997 \\
performance on multiple hosts & 29 & Růžička, 1975; Sadeghi \& Gilbert, 2000b \\
oviposition among hosts & 32 & Budenberg \& Powell, 1992; Sadeghi \& Gilbert, 2000a,c \\
intraguild predation & 6 & Benestad Hågvar, 1974; Hindayana et al., 2001 \\
\hline
\end{tabular}

\section{Field distribution}

A female' decisions about where to lay her eggs should reflect the expected subsequent welfare of her progeny, and this will vary among females (see Thompson, 1988; Courtney \& Kibota, 1990; Price, 1997). The field distribution of eggs will therefore reflect the sum of the responses of individual females, and will obscure individual variation, if any. Since most records come from two very common aphidophagous syrphids, Episyrphus balteatus and Syrphus ribesii, we can explore what the available data show by looking just at these two species.

While Episyrphus and S. ribesii larvae feed on a huge variety of aphid species, even within a single habitat (e.g. Mizuno et al., 1997), there are clear indications of host preferences. Episyrphus is recorded as being more generalized than $S$. ribesii (e.g. Ninomyia, 1957), but more usually the two species occur in different prey colonies within one habitat (Wnuk, 1972, 1979; Malinowska, 1979; Wnuk \& Medvey, 1986; Mizuno et al., 1997). There are strong indications that Episyrphus is best adapted to the aphids of Gramineae, and hence its huge abundance on many crops: it is often the dominant predator in aphid colonies on wheat, but Syrphus spp. dominate in the herb aphid colonies surrounding wheat fields (Salveter, 1998). In Poland Episyrphus was dominant in crop habitats, but $S$. vitripennis was dominant in aphid colonies on fruit trees and $S$. ribesii sub-dominant on both (Malinowska, 1979). Even among different aphids on a single hostplant, there are strong indications of selectivity (e.g. Wnuk, 1972).
Rotheray' (1980) still unpublished $\mathrm{PhD}$ work is one of the best examples of looking at multiple aphid and syrphid species, a type of study represented by only 20 studies in the literature. Working near Cardiff in Wales, he sampled all the aphid colonies of the herb, shrub and tree layers along a transect between woodland and grassland. He found that there were two distinct periods of aphid abundance, early (May-June) and late (July-August), with a gap in between. Most syrphid larvae exploited either one or the other period, but not both. For example, Episyrphus occurred only in the late period, mainly on Cavariella aphids on hogweed (Heracleum sphondylium). S. ribesii was one of only three syrphid species to exploit both periods of aphid abundance, with most of its larvae on nettle aphids (Microlophium carnosum on Urtica dioica) during the early period, and huge numbers on hogweed aphids during the late period. The other two species were Eupeodes luniger and Platycheirus scutatus. The extremely uneven distribution of $S$. ribesii larvae suggests a much higher degree of specialization than expected for this very widespread species.

Is there any evidence for substantial geographic variation in the field distribution of aphidophagous larvae among prey species? There are very few comparable data, but those that exist indicate that broad-scale consistencies in the average choices made by populations of at least these two common "generalists". There are two datasets that can be compared with that of Rotheray's from Cardiff: a season-long systematic sampling of aphid colonies from Nottingham, and a set of semi-systematic samples

TABLE 4. The four most- and least-preferred aphid prey of Episyrphus balteatus and Syrphus ribesii, as assessed from field distribution in three areas (data from Sadeghi, 2000; Rotheray, 1980; and P. Láska, unpubl.). Full details in Sadeghi et al. (in prep. ).

\begin{tabular}{|c|c|c|c|c|}
\hline Hoverfly & & Nottingham & Cardiff & Czech Republic \\
\hline \multirow[t]{2}{*}{ Episyrphus balteatus } & Most & $\begin{array}{l}\text { Aphis grossulariae on willow-herb } \\
\text { Cavariella on hogweed } \\
\text { Macrosiphum on rose } \\
\text { (Schizoneura on elm) }\end{array}$ & $\begin{array}{l}\text { Cavariella on hogweed } \\
\text { Hyalopterus on reed } \\
\text { Brevicoryne on cabbage } \\
\text { Aphis fabae on thistle }\end{array}$ & $\begin{array}{l}\text { Aphis fabae on thistle } \\
\text { Aphis fabae on spindle } \\
\text { Brevicoryne on cabbage } \\
\text { Rhopalosiphum on bird-cherry }\end{array}$ \\
\hline & Least & $\begin{array}{l}\text { Phyllaphis on beech } \\
\text { Aphis ruborum on blackberry } \\
\text { Microlophium on nettle } \\
\text { Aphis pomi on apple }\end{array}$ & $\begin{array}{l}\text { Aphis fabae on bean } \\
\text { Drepanosiphum on sycamore } \\
\text { Hyperomyzus on milk-thistle } \\
\text { Aphis fabae on mugwort }\end{array}$ & $\begin{array}{l}\text { Phyllaphis on beech } \\
\text { Aphis sambuci on elder } \\
\text { Uroleucon on cichory } \\
\text { Myzus cerasi on wild cherry }\end{array}$ \\
\hline \multirow[t]{2}{*}{ Syrphus ribesii } & Most & $\begin{array}{l}\text { Drepanosiphum on sycamore } \\
\text { Cavariella on hogweed } \\
\text { Microlophium on nettle } \\
\text { (Macrosiphum on rose) }\end{array}$ & $\begin{array}{l}\text { Cavariella on hogweed } \\
\text { Microlophium on nettle } \\
\text { Drepanosiphum on sycamore } \\
\text { Brachycaudus on campion }\end{array}$ & $\begin{array}{l}\text { Hyalopterus on plum } \\
\text { Brachycaudus on plum } \\
\text { Myzus on wild cherry } \\
\text { Aphis sambuci on elder }\end{array}$ \\
\hline & Least & $\begin{array}{l}\text { Phyllaphis on beech } \\
\text { Aphis grossulariae on willow-herb } \\
\text { (dock, apple, blackberry, elder, } \\
\text { elm aphids) }\end{array}$ & $\begin{array}{l}\text { Phyllaphis on beech } \\
\text { Myzocallis on hazel } \\
\text { Hyalopterus on Prunus } \\
\text { Hyperomyzus on milk-thistle }\end{array}$ & $\begin{array}{l}\text { Uroleucon on cichory } \\
\text { Aphis fabae on spindle } \\
\text { Uroleucon on hawksbeard } \\
\text { Aphis fabae on beet }\end{array}$ \\
\hline
\end{tabular}


done over a number of years in the Czech Republic (Table 4). Despite the only partially congruent sets of aphid colonies being sampled, there are surprising similarities in the aphid colonies in which the greatest and the least numbers of larvae were found, as study of Table 4 demonstrates. This argues for consistency of the cumulative choices of females among populations in these two "generalist" species, and suggests consistent differences in suitability among aphid species as prey.

\section{Variation in larval performance}

As Table 4 again shows, there are rather few studies in the literature that compare larval performance on different aphids. A very good example is the study of Růžička (1975) on Eupeodes corollae. He compared various measures of larval performance on 13 aphid species, and found strong differences in some measures such as mortality and pupal weight, but few differences in development times. The main difference was that elder aphids, Aphis sambuci, and hogweed aphids, Cavariella sp., were clearly toxic since all or almost all larvae died very quickly. Similarly a study of larval performance of Episyrphus and S. ribesii larvae found one aphid species, the apple aphid Aphis pomi, to be detrimental to survival (Sadeghi \& Gilbert, 2000b).

The neonate larvae are particularly vulnerable to aphid defences since they have few stored resources and must find food quickly to avoid starvation. Thus newly hatched first instars can often be killed by their first meal: young Paragus larvae, for example, were killed by cabbage aphids (Brevicoryne brassicae), and Aphis fabae from beans (but not other plants) were toxic to neonate Afrosyrphus larvae (Schmutterer, 1972a). There will probably turn out to be substantial genetically-based individual variation in the susceptibility of neonates to particular aphid-hostplant combinations.

We know (e.g., Vanhaelen et al., 2001) that host-plant defensive chemistry affects aphid chemical defences, and hence influence the detoxification enzymes in the larvae of Episyrphus. A priori we would predict an impact of enzyme induction on overall performance. As far as I know there are only two studies that set out to compare the performance of larvae feeding on one aphid species but from different host plants. Vanhaelen et al. (2002) demonstrated that hostplant effects on development times, mortality and subsequent fecundity were very significant for Episyrphus feeding on Myzus persicae or Brevicoryne brassicae from beans, mustard or oilseed rape. Hindayana (2001) showed that development times were shorter and pupal masses greater when larvae were fed potato aphids (Aulacorthum solani) on cucumbers rather than on potatoes: since sample sizes were rather small, it was not clear whether emerging females were also more fecund in the former. Development times were also shorter and pupal masses greater when fed potato aphids on cucumbers plants that had been treated with NPK fertilizer, as opposed to unfertilized control plants.

To complement this study are some strong indications from observations in the literature that this kind of variation is very important generally. For example, Kaufmann
(1973) fed Toxoptera aphids on cocoa leaves to larvae of Paragus borbonicus and they developed normally, whereas the same aphid on citrus leaves resulted in the death of all larvae within 1-3 days. Emrich (1991) studied the development of Episyrphus larvae on the lupin aphid, Macrosiphum albifrons. The larvae did not do very well, with longer development and higher mortality than normal, but this depended on which lupin species and variety was being used as the aphid hostplant: these plants differed strongly in their toxin content.

Thus host-plant effects, especially on neonates, are likely to be very important in aphidophagous syrphids.

\section{Oviposition preference and larval performance}

There are also rather few studies of the oviposition preferences of gravid female aphidophagous syrphids towards different aphid species (Table 4). A good example of such a study (Budenberg \& Powell, 1992) found that Episyrphus females would lay eggs in response to some aphid species such as cereal aphids, but not to others such as the nettle aphid, Microlophium carnosum. These responses also occurred towards the honeydew alone. In another study, female Episyrphus balteatus and Syrphus ribesii preferred to oviposit in response to particular aphid species (Sadeghi \& Gilbert, 2000a), and their preferences altered in magnitude but not in rank order with female age and host deprivation (Sadeghi \& Gilbert, 2000c). Despite the overall absence of a relationship between preference and performance (Sadeghi \& Gilbert, 2000b), some individual females of E. balteatus differed from others in their preferences, and at the individual level there appeared to be life-history trade-offs in performance with these preferences (Sadeghi \& Gilbert, 1999). In contrast there appeared to be a weak preferenceperformance correlation overall among females of $S$. ribesii (Sadeghi \& Gilbert, 2000b). Thus part of the female population of Episyrphus seems to be specialized to particular aphids as prey, whereas part of the population may consist of truly generalized individual females. In contrast, overall female $S$. ribesii agreed in their preferences and this correlated with larval performance, if only weakly. While both are generalist species, Episyrphus seems partly to be specialized at the individual level, whereas in S. ribesii it seems to be at least at the population if not the species level.

The mechanism of specialization involves female oviposition behaviour: in hoverflies like many other insects, host selection is made by ovipositing females. For a polyphagous syrphid, ovipositional preference by females has a profound effect on the performance of the offspring, since syrphid larvae probably have rather limited dispersal abilities. Even if larvae were mobile and could make their own choices to a greater or lesser extent, the suitability of the first few prey items is probably critical in determining survival (cf. Schmutterer, 1972a). There are some indications that larvae can move to new aphid colonies to a certain extent: from his samples, Banks (1968) suggested that even quite small syrphid larvae must move between plants and possibly "considerable distances". Kan (1988a,b) suggested that a single maple- 
or pea-aphid colony was insufficient to support larval development to maturity, and "older larvae are observed actively migrating among maple branches" or pea plants. Despite these opinions, most authors agree that the larvae are more or less sedentary, almost completely dependent on their mothers to choose a suitable host-prey. Much more data are needed on this point.

The role of aphid defence is beautifully demonstrated in Japanese work on the bamboo aphid, Pseudoregma (Shibao, 1998), an aphid species that has huge colonies and a soldier caste for colony defence. These soldiers pierce the eggs and neonate larvae of aphidophagous syrphids. A gravid female Eupeodes confrater circles the colony carefully: if she finds soldiers present, then she lays a batch of eggs on a spider's web nearby, up to $1 \mathrm{~m}$ away. The first larva to emerge cannibalizes the rest of the batch to provide the energy to crawl to the colony: having a meal or two before meeting a soldier will make all the difference between surviving and succumbing. If the gravid female does not encounter any soldiers in her search, then she lays single eggs in the colony, as is normal for most aphidophagous syrphids. Another syrphid, Eupeodes hakkiensis, has adapted to dealing with the aggressive soldier instars of their Ceratovacuna aphid prey by evolving a hard impenetrable eggshell, and larval behaviour that leads them to forage only at the edge of the colony, and move away when not feeding (Mizuno et al., 1997).

\section{MORTALITY}

Most of the mortality of aphidophagous syrphids arises from parasitoids and from bacterial or viral infections. Despite its importance, very little is known about diseases of syrphid larvae. In contrast there are a huge number of records of parasitoids, especially by the group of ichneumonids that are specialized to these larvae, the Diplazontinae. Little is known of other sources of mortality, including intraguild predation.

\section{Diplazontines}

Although there are many records of diplazontines parasitizing particular syrphid species, there is great confusion in the identity of both parasitoid and host. Diplazontines can be difficult to identify and many literature records of the commonest species by far, Diplazon laetatorius, are suspect. Because only the remains of the immature stages are left, identifying their syrphid hosts is also a job for a specialist. As with aphidophagous larval prey records, a false impression of generalization arises from collating these records. When experiments are carried out with particular populations of parasitoids, the species turn out to be either monophagous or oligophagous (Rotheray, 1984). There are interesting battles between parasitoid larvae within the host for control (Schneider, 1951; Rotheray, 1984), but nothing is known about the impact of differential parasitism on prey specialization. Female diplazontines respond primarily to aphid odour (Rotheray, 1981), raising the possibility of aphids being able to signal to them when attacked: nothing is known about this. Because aphid species may be distinguishable at a distance from their odours, there is every chance that diplazontine impacts vary systematically, and hence may indeed be important in influencing syrphid specialization.

\section{Intraguild predation}

An early example of studies of competition among aphidophages is the work of Benestad Hågvar (1972, 1973). She placed larvae of S. ribesii and Eup. corollae together or alone in a Petri dish with aphids, and watched the outcome. Eup. corollae larvae never cannibalized each other, and suffered greatly from attacks by $S$. ribesii larvae, which killed and ate them when hungry. S. ribesii larvae would cannibalize each other when hungry. The experimental conditions may, however, have disadvantaged the larvae of Eup. corollae, since the way these larvae move makes them specialists on stem aphids; the flat Petri dishes may have prevented the larvae from moving efficiently, and made them much more vulnerable to the more generalised movement patterns of $S$. ribesii larvae. More recently Hindayana et al. (2001) have shown that the eggs and first-instar Episyrphus are especially vulnerable to other aphidophagous insects, but they become less vulnerable as they grow. Final-instar larvae are only rarely killed by ladybirds and act as intraguild predators when confronted by lacewings and smaller ladybird instars. Such interactions are likely to be very important in influencing the choices made by ovipositing female syrphids.

\section{THE IMPACT OF HYPERPARASITISM}

Nothing is known about even the occurrence of hyperparasitoids on diplazontine parasitoids, let alone of any impact on syrphid larvae. The only information to be gleaned is that hyperparasitoids are extremely rare, and are not at all specialized. Thus the only ones ever recorded seem to be accidental (G.E. Rotheray, pers. comm.).

\section{THE IMPACT OF THIRD-PARTIES SUCH AS ANTS}

Some aphids are nearly always attended by ants, whereas others never are: why this is the case is still obscure (Way, 1963; Buckley, 1987; Stadler et al., 2003). Whatever the cause, as has been shown repeatedly via experiment, the presence of ants makes a big difference to mortality rates of aphidophages including syrphid larvae. Not surprisingly, selection caused by encounters with ants seems to be a major cause of the evolution of larval adaptations in aphidophagous syrphids. The use of ants can be viewed merely as one of a range of adaptations of aphids for defence, and predictably there are counter-adaptations by predators: Mizuno et al. (1997) highlighted a guild of syrphid predators (Paragus) with morphological adaptations that allow them to exploit ant-tended aphids.

A nice example of the complexities that ant-tending introduces to understanding prey specialization occurs in East Africa (Schmutterer, 1972a,b, 1974). Two ant species are particularly important here in tending many species of aphid: Pheidole megacephala is extremely aggressive towards any insect approaching the tended colony, and kills the larvae of anything that manages to get through its defensive shield to oviposit in the colony; 
Lepisiota (= Acantholepis) capensis is less aggressive, but still manages to prevent most gravid females from laying eggs. Only the eggs and larvae of Paragus species manage to survive the attacks of Pheidole ants to prey on the aphids of the colonies they tend, whilst larvae of some other genera also manage it in Lepisiota-tended colonies. The benefits of doing this include a complete absence of parasitism from diplazontines, which are warded off by the ants. Ant-tended colonies thus constitute a very important "enemy-free space" for many species of East African syrphids.

\section{CONCLUSIONS}

I conclude that there is plenty of evidence that the food-web context has an important and perhaps decisive influence on prey specialization in aphidophagous syrphids. This means that we should abandon typological characterization of species as "generalist" or "specialist" and move to studying and analysing variation in performance in different food webs at the individual and population levels. Without doing this we risk missing most of the important features that determine prey choices.

ACKNOWLEDGEMENTS. I thank the following: two anonymous referees for numerous suggestions; E. Branquart and D. Hindayana for permission to cite their unpublished work; P. Láska for his unpublished data on larval sampling; H. Sadeghi for his major contribution to this research programme; and my friend and colleague G. Rotheray for many fruitful discussions.

\section{REFERENCES}

Askew R.R. \& Shaw M.R. 1986: Parasitoid communities: their size, structure and development. In Waage J. \& Greathead D. (eds): Insect Parasitoids. Academic Press, London, pp. 225-287.

BANKS C.J. 1968: Effects of insect predators on small populations of Aphis fabae in the field. Entomol. Exp. Appl. 11: $169-176$.

BEnESTAD HÅgVar E. 1972: The effect of intra- and interspecific larval competition for food (Myzus persicae) on the development at $20^{\circ} \mathrm{C}$ of Syrphus ribesii and Syrphus corollae (Diptera, Syrphidae). Entomophaga 17: 71-77.

Benestad HÅgvar E. 1973: Food competition in larvae of Syrphus ribesii (L.) and Syrphus corollae (Fabr.) (Dipt, Syrphidae). Norsk Entomol. Tidsskr. 20: 315-321.

BERENBAUM M.R. 1990: Evolution of specialization in insectumbellifer associations. Annu. Rev. Entomol. 35: 319-343.

Borer E.T., Briggs C.J., Murdoch W.W. \& Swarbrick S.L. 2003: Testing intraguild predation theory in a field system: does numerical dominance shift along a gradient of productivity? Ecol. Letters 6: 929-935.

BRANQUART E. 1999: Life-History Strategies of Hoverflies with Predacious Larvae (Diptera: Syrphinae). Unpublished $\mathrm{PhD}$ Thesis, Agricultural University of Gembloux, Belgium.

BuCKLEY R.C. 1987: Interactions involving plants, Homoptera and ants. Annu. Rev. Ecol. Syst. 18: 111-135.

Budenberg W.J. \& Powell W. 1992: The role of honeydew as an ovipositional stimulant for two species of syrphids. Entomol. Exp. Appl. 64: 57-61.

Courtney S.P. \& Kibota T.T. 1990: Mother does not know best: selection of hosts by ovipositing insects. In Bernays E.A. (ed.): Insect-Plant Interactions II. CRC Press, pp. 161188 .
Courtney S.P., Chen G.K. \& Gardner A. 1989: A general model for individual host selection. Oikos 55: 55-65.

EMrich B.H. 1991: Erworbene Toxizität bei der Lupinenblattlaus Macrosiphum albifrons, und ihr Einfluss auf die aphidophagen Prädatoren Coccinella septempunctata, Episyrphus balteatus und Chrysopa carnea. [Acquired toxicity of the lupin aphid, Macrosiphum albifrons, and its influence on the aphidophagous predators Coccinella septempunctata, Episyrphus balteatus and Chrysoperla carnea]. Z. Pflkrankh. Pflschutz 98: 398-404.

Fox L.R. \& Morrow P.A. 1981: Host specialization: species property or local phenomenon? Science 211: 887-893.

Harvey J.A., van DAM N.M. \& Gols R. 2003: Interactions over four trophic levels: foodplant quality affects development of a hyperparasitoid as mediated through a herbivore and its primary parasitoid. J. Anim. Ecol. 72: 520-531.

HindayAnA D. 2001: Resource exploitation by Episyrphus balteatus (DeGeer) (Diptera: Syrphidae) and intraguild predation. Unpublished $\mathrm{PhD}$ thesis, University of Hannover, Germany.

Hindayana D., Meyhofer R., Scholz D. \& Poehling H.-M. 2001: Intraguild predation among the hoverfly Episyrphus balteatus de Geer (Diptera: Syrphidae) and other aphidophagous predators. Biol. Contr. 20: 236-246.

HoDeK I. 1993: Habitat and food specificity in aphidophagous predators. Biocontr. Sci. Technol. 3: 91-100.

JACKSON J.B.C. 1994: Community unity. Science 264: $1412-1413$.

JAENIKE J. 1990: Host specialization in phytophagous insects. Annu. Rev. Ecol. Syst. 21: 243-273.

JANZ N., Nylin S. \& Wedell N. 1994: Host plant utilization in the Comma butterfly: source of variation and evolutionary implications. Oecologia 99: 132-140.

KAN E. 1988a: Assessment of aphid colonies by hoverflies. 1. Maple aphids and Episyrphus balteatus (de Geer) (Diptera: Syrphidae). J. Ethol. 6: 39-48.

KAN E. 1988b: Assessment of aphid colonies by hoverflies. II. Pea aphids and 3 syrphid species: Betasyrphus serarius (Wiedemann), Metasyrphus frequens Matsumura and Syrphus vitripennis (Meigen) (Diptera: Syrphidae). J. Ethol. 6: 135-142.

KaUfmann T. 1973: Biology of Paragus borbonius (Diptera: Syrphidae) as predator of Toxoptera aurantii (Homoptera: Aphididae) attacking cocoa in Ghana. Am. Midl. Nat. 90: 252-256.

Kessler A. \& BALdwin I.T. 2001: Defensive function of herbivore-induced plant volatile emissions in nature. Science 291: 2141-2144.

Leibold M.A., Holyoak M., Mouquet N., Amarasekare P., Chase J.M., Hoopes M.F., Holt R.D., Shurin J.B., Law R., Tilman D., Loreau M. \& Gonzalez A. 2004: The metacommunity concept: a framework for multi-scale community ecology. Ecol. Letters 7: 601-613.

Malcolm S.B. 1992: Prey defence and predator foraging. In Crawley M.J. (ed.): Natural Enemies: The Population Biology of Predators, Parasites and Diseases. Blackwell Scientific, Oxford, pp. 458-475.

MalinowsKa D. 1979: Communities of aphidophagous syrphids (Diptera, Syrphidae) in the Lublin region. Memorab. Zool. 30: 37-62.

Matsumoto T., Itioka T. \& Nishida T. 2003: Cascading effects of a specialist parasitoid on plant biomass in a Citrus agroecosystem. Ecol. Res. 18: 651-659.

McGraw J.B. \& Caswell H. 1996: Estimation of individual fitness from life-history data. Am. Nat. 147: 47-64.

Mizuno M., Itioka T., Tatematsu Y. \& Ito Y. 1997: Food utilization of aphidophagous hoverfly larvae (Diptera: Syrphidae, 
Chamaemyiidae) on herbaceous plants in an urban habitat. Ecol. Res. 12: 239-248.

de Moraes C.M., Lewis W.J., Paré P.W., Alborn H.T. \& TumLINSON J.H. 1998: Herbivore-infested plants selectively attract parasitoids. Nature 393: 570-573.

De Moraes C.M. \& Mescher M.C. 2004: Biochemical crypsis in the avoidance of natural enemies by an insect herbivore. Proc. Nat. Acad. Sci. USA 101: 8993-8997.

Morantz R. \& Brower L.P. 1998: Geographical and temporal variation of cardenolide-based chemical defences of Queen butterflies (Danaus gilippus) in northern Florida. J. Chem. Ecol. 24: 905-932.

MÜller C.B. \& Godfray H.C.J. 1999: Indirect interactions in aphid-parasitoid communities. Res. Popul. Ecology 41: 93-106.

NG D. 1988: A novel level of interactions in plant-insect systems. Nature 334: 611-613.

NinOMYIA E. 1957: On the food habits of some aphidophagous syrphid larvae. II. Jap. J. Appl. Entomol. Zool. 1: 186-192 [in Japanese, English abstr.]

NYLIN S. \& JANZ N. 1993: Oviposition preference and larval performance in Polygonia c-album. Ecol. Entomol. 18: 394-398.

Ode P.J., Berenbaum M.R., Zangerl A.R. \& Hardy I.C.W 2004: Host plant, host-plant chemistry, and the polyembryonic parasitoid Copidosoma sosares: indirect effects in a tritrophic interaction. Oikos 104: 388-400.

PricE P.W. 1997: Insect Ecology. 3rd ed. Wiley, New York, 874 pp.

Price P.W., Bouton C.E., Gross P., McPheron B.A., Thompson J.N. \& Weis A.E. 1980: Interactions among three trophic levels: influence of plants on interactions between insect herbivores and natural enemies. Annu. Rev. Ecol. Syst. 11: 41-65.

RitLAND D.B. 1991: Unpalatability of Viceroy butterflies (Limenitis archippus) and their purported mimicry models, Florida Queens (Danaus gilippus). Oecologia 88: 102-108.

Rojo S., Gilbert F., Marcos-Garcia M.A., Nieto J.M. \& Mier M.P. 2003: A World Review of Predatory Hoverflies (Diptera, Syrphidae: Syrphinae) and Their Prey. Centro Iberoamericano de la Biodiversidad, Universidad de Alicante, $320 \mathrm{pp}$.

Rotheray G.E. 1980: The Life Cycle and Distribution of Syrphus ribesii (L.) (Diptera, Syrphidae) Occurring in the British Isles. Unpubl. $\mathrm{PhD}$ Thesis.

RotheRAY G.E. 1981: Host searching and oviposition behaviour of some parasitoids of aphidophagous Syrphidae. Ecol. Entomol. 6: 79-87.

Rotheray G.E. 1984: Host relations, life cycles and multiparasitism in some parasitoids of aphidophagous Syrphidae (Diptera). Ecol. Entomol. 9: 303-310.

Rutledge C.E., Robinson A.P. \& Eigenbrode S.D. 2003: Effects of a simple plant morphological mutation on the arthropod community and the impacts of predators on a principle insect herbivore. Oecologia 135: 39-50.

RŮŽIČKA Z. 1975: The effects of various aphids as larval prey on the development of Metasyrphus corollae (Dipt., Syrphidae). Entomophaga 20: 393-402.

SAdeghi H. 2000: Oviposition Preference and Larval Performance in Hoverflies. Unpubl. PhD Thesis, Nottingham University, UK.

SADEGHI H. \& Gilbert F. 1999: Individual variation in oviposition preference, and its interaction with larval performance in an insect predator. Oecologia 118: 405-411.

SAdEGHI H. \& Gilbert F. 2000a: Oviposition preferences in aphidophagous hoverflies. Ecol. Entomol. 25: 91-100.

SADEGHI H. \& Gilbert F. 2000b: Suitability of different aphids as larval food for the predatory larvae of hoverflies (Diptera: Syrphidae). J. Anim. Ecol. 69: 771-784.
Sadeghi H. \& Gilbert F. 2000c: The effect of egg load and host deprivation on oviposition behaviour in aphidophagous hoverflies. Ecol. Entomol. 25: 101-108.

SALVETER R. 1998: The influence of sown herb strips and spontaneous weeds on the larval stages of aphidophagous hoverflies (Dipt., Syrphidae). J. Appl. Entomol. 122: 103-114.

SCHMUTTERER H. 1972a: Zur Beutespezifität polyphager, räuberischer Syrphiden Ostafrikas. [On the food specificity of polyphagous predatory syrphids of East Africa.] Z. Angew. Entomol. 71: 278-286.

SCHMUTTERER H. 1972b: Untersuchungen über das Verhalten von zwei ostafrikanischen Ameisenarten genenüber räu berischen Syrphiden. [Studies on the behaviour of two species of East African ants towards predacious syrphids.] Entomophaga 17: 443-453.

SCHMUTTERER H. 1974: Ökologische Untersuchungen an entomophagen Syrphiden und ihren Parasiten im Hochland von Kenia (Ostafrika). [Ecological studies on entomophagous syrphids and their parasitoids in the Kenya highlands (East Africa).] Z. Angew. Entomol. 75: 42-67.

SCHNEIDER F. 1951: Einige physiologische Beziehungen zwischen Syrphidenlarven und ihren Parasiten. [Some physiological relationships between syrphid larvae and their parasites.] Z. Angew. Entomol. 33: 151-162.

SchoOnhoven L.M., Jermy T. \& VAN LOON J.J.A. 1998: InsectPlant Biology. Chapman \& Hall, London, 409 pp.

Shibao H. 1998: [An offensive and defensive battle between the hoverfly Eupeodes confrater and the soldier-producing aphid Pseudoregma bambucicola.] Insectarium 35(8): 224-233 (in Japanese).

SimBERLOFF D. 1980: A succession of paradigms: essentialism to materialism and probabilism. Synthèse 43: 3-39.

Stadler B., Kindlmann P., Šmilauer P. \& Fiedler K. 2003: A comparative analysis of morphological and ecological characters of European aphids and lycaenids in relation to ant attendance. Oecologia 135: 422-430.

TAuber C.A. \& TAuber M.J. 1987: Food specificity in predacious insects: a comparative ecophysiological and genetic study. Evol. Ecol. 1: 175-186.

THOMPSON J.N. 1988: Evolutionary ecology of the relationship between oviposition preference and performance of offspring in phytophagous insects. Entomol. Exp. Appl. 47: 3-14.

Vanhaelen N., Haubruge E., Lognay G. \& Francis F. 2001: Hoverfly glutathione S-transferases and effect of Brassicaceae secondary metabolites. Pestic. Biochem. Physiol. 71: 170-177.

Vanhaelen N., Gaspar C. \& Francis F. 2002: Influence of prey host plant on a generalist aphidophagous predator, Episyrphus balteatus (Diptera: Syrphidae). Eur. J. Entomol. 99: 561-564.

WAY M.J. 1963: Mutualism between ants and honeydewproducing Homoptera. Annu. Rev. Entomol. 8: 307-344.

WNUK A. 1972: Investigations on the species composition of predaceous Syrphidae (Diptera) occurring in the colonies of aphids on fruit trees and shrubs. (in Polish, English abstr.). Pol. Pis. Entomol. 42: 235-247.

WNUK A. 1979: Episyrphus balteatus (De Geer, 1776) (Diptera, Syrphidae) as an Aphid (Homoptera: Aphidoidea) Predator. Akademia Rolnicza im. Hugona Koltaja w Krakowie, Rozprawa habilitacyjna 72, 64 pp. [in Polish, English and Russian abstr.]

Wnuk A. \& Medvey M. 1986: Syrphid predators (Diptera, Syrphidae) occurring in the colonies of currant aphid (Homoptera, Aphidinea). Pol. Pis. Entomol. 56: 209-215 [in Polish, English and Russian abstr.]

Received September 22, 2004; revised and accepted April 12, 2005 